\title{
36. METEOR CORES 12309: LATE PLEISTOCENE REFERENCE SECTION FOR INTERPRETATION OF THE NEOGENE OF SITE 397
}

\author{
Gerhard F. Lutze, Michael Sarnthein, ${ }^{1}$ Bernhard Koopmann, and Uwe Pflaumann, \\ Geologisches Institut der Universität, D-2300 Kiel, West Germany \\ Helmut Erlenkeuser, Institut für Kernphysik der Universität, D-2300 Kiel, West Germany \\ and \\ Jörn Thiede, ${ }^{1}$ Institutt for geologi, Universitetet i Oslo, Blindern, Oslo 3, Norway
}

\begin{abstract}
Meteor Cores 12309-2 and -3 preserve a detailed oxygen-isotope record of the late Pleistocene as penetrated at DSDP Site 397. A 9.4meter-thick sediment section was analyzed in detail for foraminiferal and sedimentary components. Fluctuations and stratigraphic evidence of both benthic and planktonic foraminifers follow the surface-water oxygen-isotope curve, which served to calibrate the benthic foraminiferal record of the deep-water hydrographic evolution. The Stage $2 / 3$ boundary was dated at approximately $24,000 \mathrm{yr}$ B.P. The various stratigraphic curves resolve secondary climatic phases within oxygen-isotope Stages 1 and 2 (e.g., three cold pulses). The oscillations have a duration of 2000 to 4500 years (i.e., 25 to 60 $\mathrm{cm}$ sediment thickness), and are also clearly evidenced in other continental-margin environments. Sedimentation rates of 7 to 9 $\mathrm{cm} / 1000$ years during warm and 15 to $20 \mathrm{~cm} / 1000$ years during cold stages, were calculated.

Some increases of polar and sub-polar planktonic foraminifers Globigerina bulloides and $G$. pachyderma (upper Stage 3 and early Stage 1) do not correspond to the oxygen-isotopic curve, but parallel uncommon maxima of the number and species composition of benthic foraminifers as well as of the biogenic-opal fraction. These features are related to upwelling pulses.

Calibration of the marine sedimentary record against well-dated evidence of continental climate evolution reveals a massive eoliandust supply, extreme aridity, and stronger winds during the cold Stages 2, 4, and ?6. These are opposed to low dust input and increased wetness during the warm Stages 1, 3, and 5a, when stained quartz dust might indicate the formation and erosion of red soils.

A continuous downslope transport of sediment occurs; based on an abundance of displaced shallow-water foraminifers in the finesand fraction. Such transport may be responsible for up to one-third of the Neogene sedimentation at DSDP Site 397.
\end{abstract}

\section{OBJECTIVES}

Two Meteor cores were obtained close to DSDP Site 397 from the western African upper continental rise. The joint 9.4-meter sediment section from both cores was chosen as a reference section to calibrate the sedimentary and faunal record against reported fluctuations of different oceanographic and climatic variables during the late Pleistocene and Holocene on and off northwestern Africa. This key information is indispensable when trying to understand the results from the Neogene and the Quaternary at DSDP Site 397.

By employing oxygen-isotope data from deep-sea cores, various authors (see Shackleton and Opdyke,

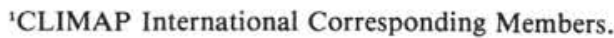

1976) have identified 10 climatic cycles (glacial and interglacial stages) during the narrow-spaced global timescale of the last 700,000 years. Transitions between warm and cold stages have been shown to have a duration of a few thousand years or shorter. It was our particular interest to re-examine some of the results of Chamley et al. (1977) and Thiede (1977) in the light of new stratigraphic information, sedimentological data, and new evidence on the continental climatic fluctuations during the past 100,000 years. Therefore, the first purpose of this study is the application of the oxygenisotope stratigraphy to the two Meteor cores and to examine if and in which detail benthic and planktonic fluctuations reflect the cycles of the oxygen-isotopic curve. Resulting late Pleistocene sediment-accumulation rates are expected to serve as a relative measure for the Quaternary and Neogene section of Site 397. 
A second objective of this paper is to tentatively define the influence of African continental arid and wet phases on the terrigenous sediment input to the continental margin, and to correlate this information on wetness to global climatic stages. This question is in part related to the problem of the identification and the significance of eolian dust-derived marine sediment.

The interaction of sea-level history and down-slope sediment displacement as indicated by benthic foraminifers constitutes a further objective of this reference section. A critical assessment of the smear-slide results as compared to those of other methods is a methodological purpose of this paper.

\section{DESCRIPTION OF CORE}

\section{Position and Sampling}

A kasten Core GIK 12309-2 (350-cm long) was obtained from 2850 meters water depth and a sphincter piston Core GIK 12309-3 (750-cm long) from 2760 meters. Their location was $26^{\circ} 50.3^{\prime} \mathrm{N}$ and $15^{\circ} 06.6^{\prime} \mathrm{W}$ (Seibold, 1972). With the exception of Thiede (who used shipboard samples), all authors evaluated the same set of core samples, thus enabling a direct correlation of their data.

\section{Sediment Colors and Megascopic Structures}

The top $70 \mathrm{~cm}$ of Core 12309-2 are brownish, with a gradual transition below $65 \mathrm{~cm}$ to grayish muds at depths of 100 to $300 \mathrm{~cm}$ (details in Figure 1A). Contrary to Diester-Haass (1976) and Chamley et al. (1977), Core 12309-3 also contains brownish mud layers. One lies at the top $(0$ to $11 \mathrm{~cm})$ and is sharply delineated from the underlying light gray sediments. The other brownish bed occurs at 540 to $613 \mathrm{~cm}$ depth, gradually increasing in color intensity from 540 to $560 \mathrm{~cm}$, then abruptly stopping at $613 \mathrm{~cm}$.

Megascopic burrowing fabrics are concentrated in Core 12309-3 at sample intervals of 120 to 140,160 to 200,250 to 350,565 to 575 , and 613 to $625 \mathrm{~cm}$. By radiography, A. Wetzel (personal communication) has observed a major discontinuity (shearing faults) at 613 $\mathrm{cm}$, which truncates all the primary and biogenic sediment structures. This discontinuity also is indicated by a change of color. Below this follows a zone (613 to 710 $\mathrm{cm}$ ) of minor sediment deformation underlain by recumbent folds; these indicate a second major plane of postdepositional gliding at 710 to $717 \mathrm{~cm}$ (both levels marked in Figure 1). Minor deformation fabrics continue to the base of the core. A purely deformational contact can probably also be assumed for the abrupt color change at $12 \mathrm{~cm}$ depth in Core 12309-3.

\section{Oxygen-lsotope Stratigraphy}

The oxygen-isotope results (Figure 1B) are based on the planktonic species Globigerina bulloides s. str. because of its relative abundance in all samples. In some samples, left-coiling specimens were analyzed separately; but, in agreement with Pflaumann (1975), no specific effect of the coiling direction on the oxygen-isotope composition was observed. Globigerinoides trilobus sacculifer with a sack-like last chamber was chosen for comparative oxygen-isotopic measurements in the uppermost $60 \mathrm{~cm}$ of Cores 12309-2 and 309-3. The foraminiferal tests were cracked and washed ultrasonically, cleansed additionally by hand under the binocular, dried at $40^{\circ} \mathrm{C}$, then directly reacted under vacuum conditions at $50^{\circ} \mathrm{C}$ with 100 per cent $\mathrm{H}_{3} \mathrm{PO}_{4}$. Carbon and oxygen isotopes were measured on the V.G. Micromass model 602 instrument at the Institut für Kernphysik at Kiel University.

The oxygen-isotope ratios of Globigerinoides sacculifer and Globigerina bulloides were in good agreement, although $G$. sacculifer appears slightly lighter in $\delta^{18} \mathrm{O}$ than $G$. bulloides. This difference in $\delta^{18} \mathrm{O}$ could well reflect the different habitats of these species (Vergnaud-Grazzini, 1975); G. bulloides seems to be more abundant in the cooler water mass in the upwelling area, while $G$. sacculifer is most likely to have grown in the warmer pelagic surface water outside the upwelling area (Thiede, 1975). Malmgren and Kennett (1977), who found a similar difference between $G$. bulloides and Globigerina falconensis, suspect $G$. bulloides lives at a greater average depth than the surface-dweller $G$. falconensis.

A more pronounced difference between $G$. bulloides and $G$. sacculifer was seen in the carbon-isotopic composition. The $\delta^{13} \mathrm{C}$ results indicate that $G$. sacculifer forms its carbonate test in near equilibrium with the bicarbonate of the surrounding water, while $G$. bulloides is obviously influenced by isotopically light metabolic $\mathrm{CO}_{2}$. Bé and Hamlin (1967) and Bé et al. (1977) reported a greenish protoplasma of $G$. bulloides as well as probably symbiotic algae in $G$. sacculifer. These observations suggest that the different role of metabolism of photosynthesizing symbionts might be responsible for a higher concentration of metabolic carbon within the organism of $G$. bulloides.

$\delta^{18} \mathrm{O}$ and $\delta^{13} \mathrm{C}$ results of the two cores were matched at $202 \mathrm{~cm}$ depth in Core $12309-2$ corresponding to $12 \mathrm{~cm}$ in Core 12309-3. The fit is based mainly on the overlap of the benthic foraminiferal record (Figure 2), and is supported by the evidence of planktonic foraminifers and pelagic gastropods. The uppermost $12 \mathrm{~cm}$ of Core 12309-3 was found to be an allochthonous slab belonging to the upper middle part of oxygen-isotopic Stage 1.

The combined oxygen-isotope curve from both cores (Figure 1C) closely resembles those derived from other northwestern African continental margin cores as well as those from other ocean margins (Thiede, 1977; Ninkovich and Shackleton, 1975; Emiliani et al., 1975). Accordingly, oxygen-isotope stage boundaries were defined in Figure 1. Oxygen-isotope Stage 1 extends down to $125 \mathrm{~cm}$ in Core 12309-2. An isolated light oxygen peak at the base of Stage 1 might correspond to meltwater related peaks observed at the same stratigraphic position in the Gulf of Mexico and elsewhere (Emiliani et al., 1975; Shackleton and Kennett, 1975; Berger, personal communication). This first $\delta^{18} \mathrm{O}$ minimum at the base of Stage 1 precedes a marked pulse of $\delta^{13} \mathrm{C}$ in the shells. 
$12309-2$ 12309-3

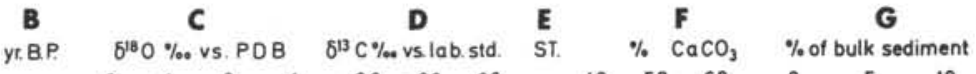

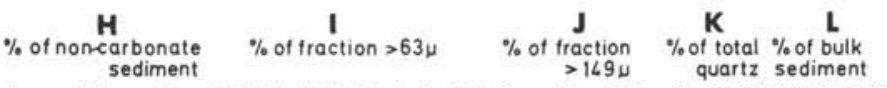

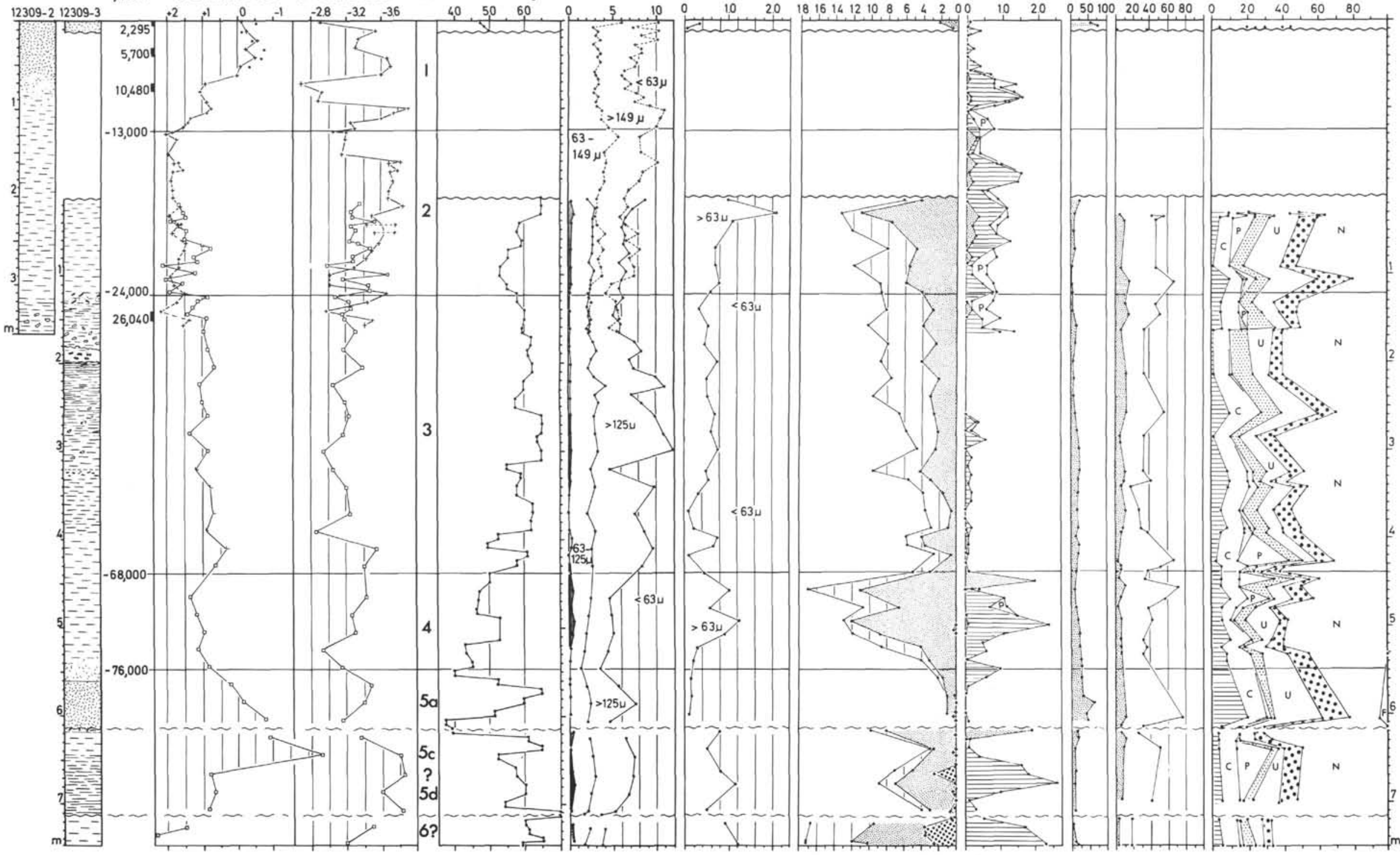

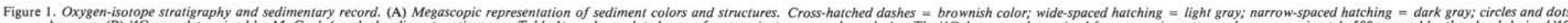
=

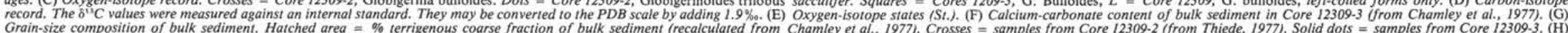
Grain-size composition of bulk sediment. Hatched area $=\%$ terrigenous coarse fraction of bulk sediment (recalculated from Chamley et al., 1977$)$. Crosses $=$ samples from Core $12309-2$ (from Thiede, 1977$)$. Solid dots $=$ samples from Core 12309-3. (H)
Grain-size composition of non-carbonate sediment (recalculated from our own data; Chamley et al., 1977; and Diester-Haass, 1977). (1) Coarse-fraction composition of Core 12309-3 (cumulative percentage recalculated from Chamley et al., 1977 ; Diester-

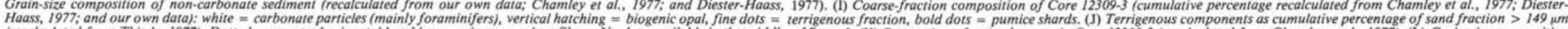
(recalculated from Thiede, 1977$)$. Dotted $=$ quartz; horizontal hatching $=$ mica; $p=$ plant fibers. No data available in the middle of Stage 3 . (K) Proportion of stained quartz in Core 12309.3 (recalculated from Chamley et al., 1977$)$. (L) Grain-size composition

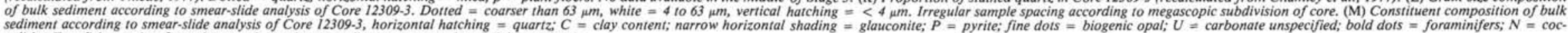
coliths; $F=$ fish remains. Irregular sample spacing according to megascopic subdivision of core. 


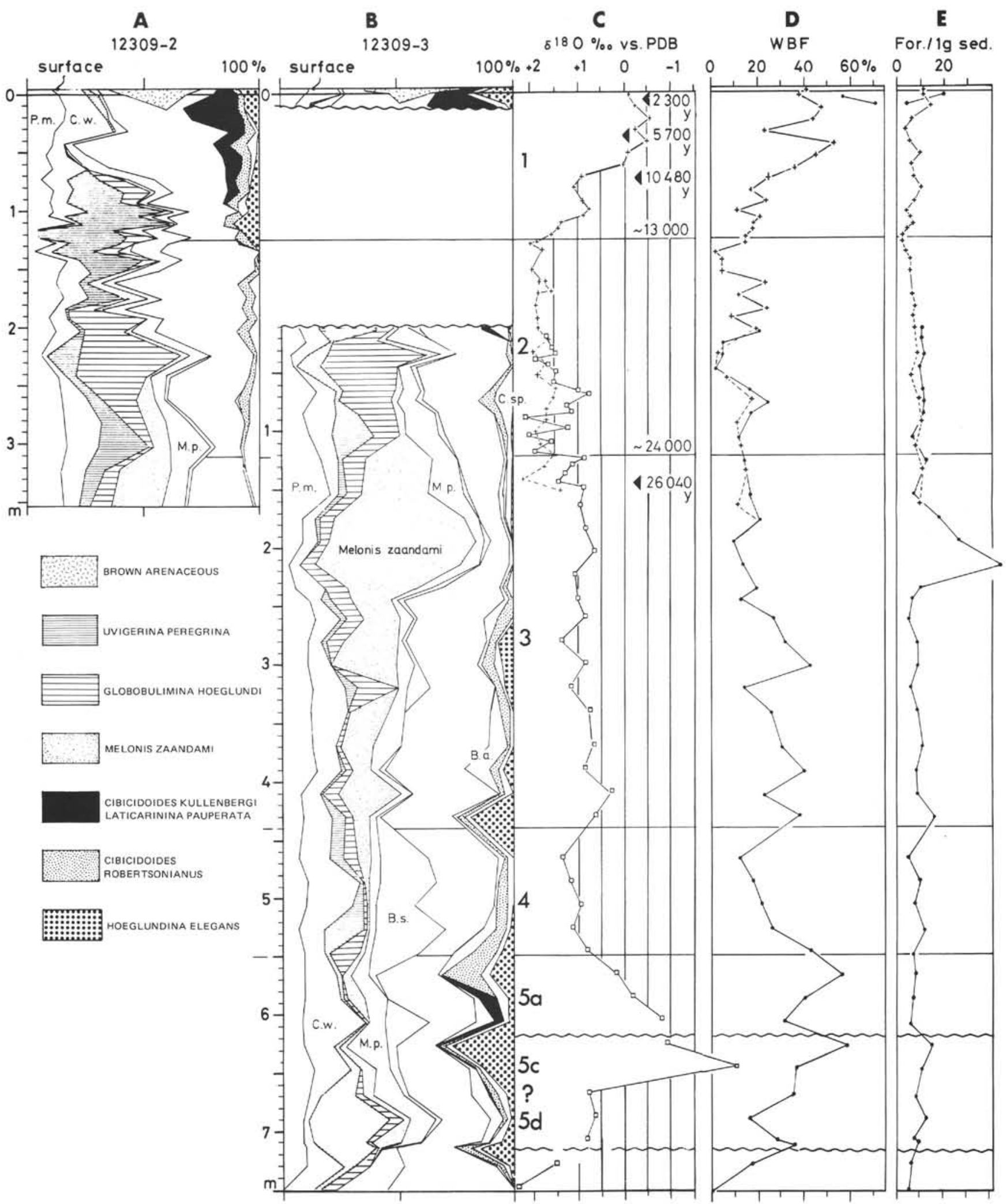

Figure 2. Benthic foraminifers $>250$ microns. (A, B) Cumulative percentage diagrams of Cores 12309-2 and 12309-3, correlation by means of Globobulimina maximum (see Foraminiferal Record in text). P.m. = Pyrgo murrhina, C.w. $=$ Cibicidoides wuellerstorfi, M.p. $=$ Melonis pompilioides, B.s. $=$ Bulimina striata, B.a. $=$ Bulimina aculeata, C. $s p .=$ Cibicicoides sp. 1. (C) Oxygen isotopic curve (see Figure 1C). (D) 'Warmth" indicating benthic foraminifers $(W B F)$, percentage of "warm"' and "cool" species. Note: 18,000-year level, clearly indicated at $44 \mathrm{~cm}$, Core 12309-3, corresponding to the second cold pulse in Stage 2 (Figure 2C). (E) Benthic foraminiferal number (number of specimens/gram of dry sediment). 
Stage 2 contains three characteristic maxima. A $\delta^{13} \mathrm{C}$ peak parallels the transition to the $\delta^{18} \mathrm{O}$ maximum in the middle of Stage 2 (Core 12309-3, $90 \mathrm{~cm}$ ). The base of Stage 2 lies at $313 \mathrm{~cm}$ in Core $12309-2$ and at $123 \mathrm{~cm}$ in Core 12309-3. This boundary is defined by a most pronounced change in the oxygen-isotope ratio and is preceded by a small, but distinct third $\delta^{18} \mathrm{O}$ maximum.

Below a section with moderate oscillations during Stage 3, high oxygen-isotopic ratios again mark Stage 4 between 440 and $550 \mathrm{~cm}$ depth. Stage 5, only represented by parts of Sub-stage 5a, lies disconformably over sediments tentatively attributed to Sub-stages $5 \mathrm{c}$ and $5 \mathrm{~d}$ and to late Stage 6.

Absolute ages are assigned to the stage boundaries shown in Figure 1B by correlating the isotopic curve with the results of Shackleton and Opdyke $(1973,1976)$, with accurately dated ice-cap stratigraphy of North America (Dreimanis and Goldthwait, 1973; Stuiver and Yang, 1977) and northern Europe (summarized by Duphorn, 1976), and by the use of a few ${ }^{14} \mathrm{C}$ datings (Figure 1 , Table 1 ). The Stage $2 / 3$ boundary was correlated to 24,000 yr B.P. (our ${ }^{14} \mathrm{C}$ data; Dreimanis and Goldthwait, 1973; N. J. Shackleton, personal communication), instead of the 32,000 years of age of Shackleton and Opdyke (1973, 1976); Hays et al. (1976); and Thiede (1977).

The age model of Emiliani et al. (1975), which strongly supports an older age for the stage boundary at 30,000 yr B.P. by radiocarbon data, was not used. Emiliani's high ${ }^{14} \mathrm{C}$ ages are based on bulk carbonate from the continental slope with extremely high sediment-accumulation rates during the cold stages. A significant proportion of this carbonate might consist of redeposited (i.e., older) shallow-water sediments from the former dry shelves, as also indicated by an inversion of ${ }^{14} \mathrm{C}$ data during the maximum cold. The (non-turbiditic) allochthonous carbonate of Emiliani's core was probably supplied by a grain-by-grain transport analogous to the one observed at the present location off northwestern Africa (Bein and Fütterer, 1977). This mode of transport in up-

TABLE 1

${ }^{14} \mathrm{C}$ Ages of Cores 12309

\begin{tabular}{|c|c|c|c|c|}
\hline Lab. No. & $\begin{array}{l}\text { Interval } \\
(\mathrm{cm})\end{array}$ & $\begin{array}{c}\text { Fraction } \\
\text { Dated }\end{array}$ & $\begin{array}{l}\text { Conv. }{ }^{14} \mathrm{C} \text { Age } \\
\text { (yr. before } \\
\text { A.D. 1950) }\end{array}$ & $\begin{array}{l}\text { Error } \\
( \pm 1 \sigma)\end{array}$ \\
\hline \multicolumn{5}{|l|}{ Core $12309-2$} \\
\hline $\begin{array}{l}\text { Hv } 6778 \\
\text { Hv } 6779 \\
\text { Hv } 6780 \\
\text { Hv } 6781\end{array}$ & $\begin{array}{c}1-5 \\
30-40 \\
70-80 \\
330-340\end{array}$ & $\begin{array}{l}\text { Org. C } \\
\text { Org. C } \\
\text { Org. C } \\
\text { Org. C }\end{array}$ & $\begin{array}{r}2295 \\
5700 \\
10480 \\
26040\end{array}$ & $\begin{array}{l} \pm 480 \\
\pm 430 \\
\pm 160 \\
\pm 650\end{array}$ \\
\hline \multicolumn{5}{|l|}{ Core 12309-3 } \\
\hline KI 1317.011 & $39-43$ & $\begin{array}{l}\text { Planktonic } \\
\text { carbonate } \\
>125 \mu \mathrm{m}\end{array}$ & 20100 & $\begin{array}{l}+2100 \\
-1700\end{array}$ \\
\hline KI 1317.021 & $39-43$ & $\begin{array}{l}\text { Planktonic } \\
\text { carbonate } \\
<125 \mu \mathrm{m}\end{array}$ & 19100 & $\begin{array}{l}+2600 \\
-2000\end{array}$ \\
\hline
\end{tabular}

Note: Hv: ${ }^{14} \mathrm{C}$ lab. Hannover; Geyh, 1976 ; KI: ${ }^{14} \mathrm{C}$ lab. Kiel; carbonate samples prepared by L. Diester-Haass. welling areas of intense bioturbation can only be detected by detailed studies of grain sizes of benthic fauna, and coarse fractions.

\section{Foraminiferal Record: Benthos}

A total of 73 samples from both cores was statistically analyzed. To avoid problems with varying contamination by allochthonous components, the study was based exclusively on the fraction larger than $250 \mathrm{mi}-$ crons. Dominant species and species of ecological importance are described in Lutze (this volume). Species groups characterizing warm or cool phases have been used according to Lutze (1978). The warmth-loving group is called WBF for convenient reference and contains: Laticarinina pauperata, Cibicidoides kullenbergi, Cibicidoides robertsonianus, Cibicidoides sp., and Hoeglundina elegans. The "cool" group consists of Pyrgo murrhina, Cibicidoides wuellerstorfi, Uvigerina peregrina, and Globobulimina hoeglundi. WBF values were calculated as a percentage of both the cool and the warm species, ignoring species of minor ecological significance.

The dominant pattern of faunal fluctuation is shown in Figure 2. The WBF group (right side of Figure 2B) as well as the derived WBF curve (Figure 2D) follow the general trend of the isotopic curve (Figure 2C). Good agreement was found in isotope Stage 1 (Core 12309-2), Stage 2, and Stage 4/5a boundary, whereas no strict peak correlation was found for Stage 3. The same applies to the planktonic curve (Figure 3C, D). Cool periods are characterized by Uvigerina-maxima.

If one compares the two cores, the most significant patterns are formed by the extreme maxima of two species: (1) Globobulimina hoeglundi (at $220 \mathrm{~cm}$ in Core 12309-2, at $44 \mathrm{~cm}$ in Core 12309-3), and (2) Melonis zaandami (incomplete at $350 \mathrm{~cm}$ in Core 12309-2, at 214 $\mathrm{cm}$ in Core 12309-3). Further similar maxima do not occur throughout the cores or in the Pleistocene section of DSDP Site 397. Therefore, they are used to correlate the cores: $202 \mathrm{~cm}$ in Core $12309-2$ fits with $12 \mathrm{~cm}$ in Core 12309-3. To verify this correlation, the WBF curves were superimposed and an excellent fit was found (Figure 2D). The top $5 \mathrm{~cm}$ of Core 12309-3 contain "brown arenaceous" foraminifers (such as Cyclammina, Hyperammina, Saccorhiza, etc.), which dissolve when buried deeper in the sediment. Accordingly, they indicate true surface sediment and we correlate this part of the section to the top of Core 12309-2. Grab Sample 12309-1 gave similar results showing that the uppermost core samples do not represent the actual surface sediment, but instead are close to it.

\section{Foraminiferal Record: Plankton}

The lower grain-size limit for the planktonic foraminiferal counts was set at $150 \mu \mathrm{m}$. The weighed 150 to 250,250 to 500 , and 500 to $1000 \mu \mathrm{m}$ subfractions were counted separately, and the bulk percentages of the $>150 \mu \mathrm{m}$ fraction was computed from the particle percentages and the weight percentages of the subfractions. The taxonomic categories were defined by Pflaumann (1975) and Thiede (1977). The coiling ratio 


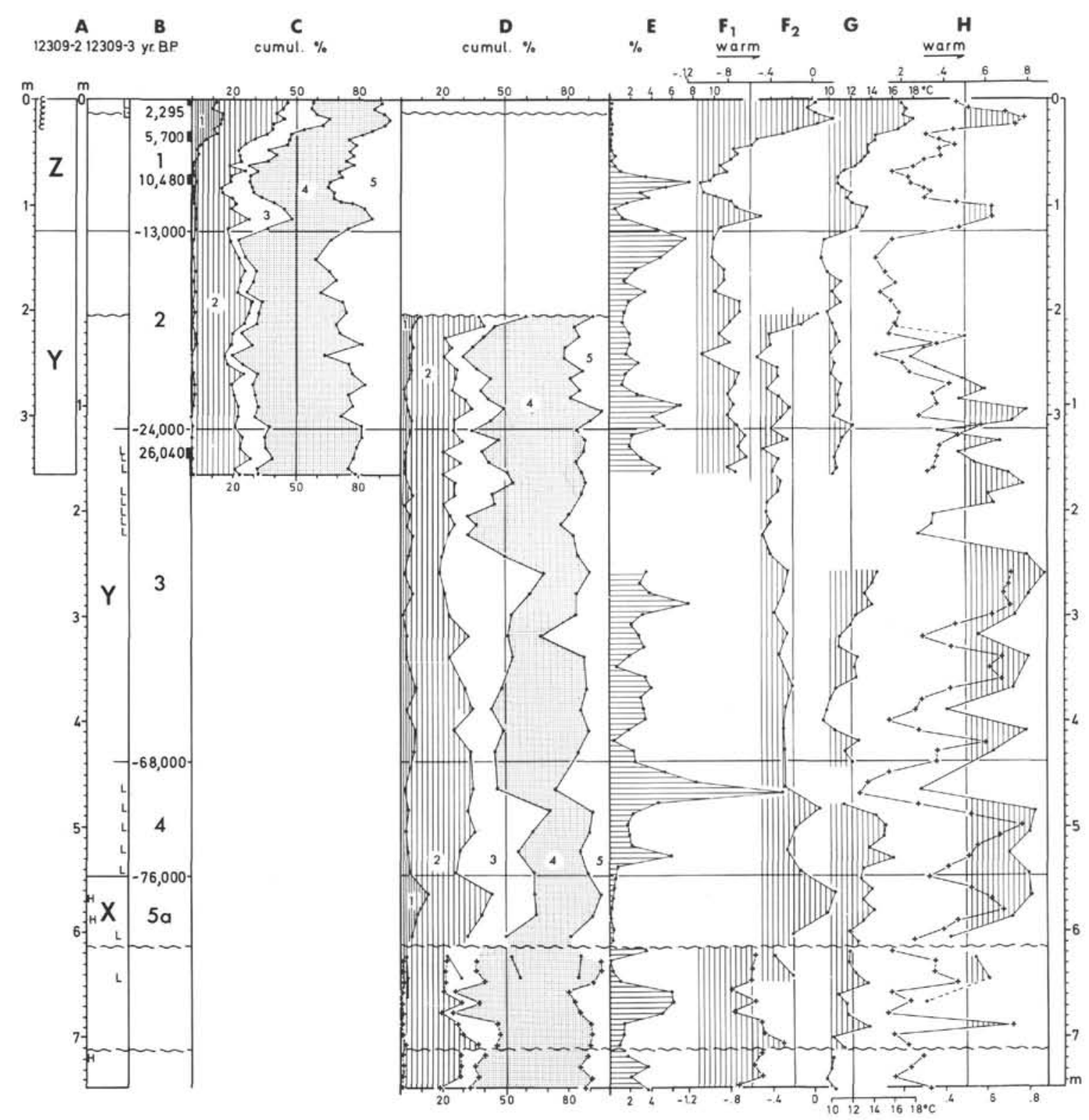

Figure 3. Paleo climatic record of planktonic foraminifers and biogenic opal. The differences of parallel counts were derived from different taxonomic concepts, mainly of the pachyderma-dutertrei intergrades. (A) Interrelation between the cores and climatic zonation, (Z, Y, X-zone based) on Ericson and Wollin, 1956; regionally compensated). $C=$ presence of Globorotalia cultrata, $H=$ presence of Globorotaloides hexagonus, $L=$ predominantly leftcoiling Globorotalia truncatulinoides. $(B)^{14} \mathrm{C}$ ages (see Table 1) and correlated ages. Bold numbers: oxygen-isotope stages (compare with Figure 1B). (C, D) Faunal composition of the planktonic foraminifers divided into five ecological groups, mainly according to Be and Tolderlund (1971). Ecological groups (left to right) parallel decreasing temperatures: 1 = tropical, $2=$ sub-tropical, $3=$ intermediate, $4=$ sub-polar $(\mathrm{G}$. bulloides dom.), $5=$ polar species group. Lower grain-size limit $150 \mu \mathrm{m}$. Figure 3 (C) represents Core 12309-2 (Thiede data); Figure 3 (D) represents Core 12309-3 (Pflaumann data), with crosses for data from Thiede, 1977. (E) Percentages of biogenic opal of the total biogenic opal plus planktonic foraminifers in the $>149 \mu \mathrm{m}$ fraction (data from Thiede, 1977, recalculated). No data available above $260 \mathrm{~cm}$, Core 12309-3. $\left(F_{l}, F_{2}\right.$ ) Paleotemperature Index 2 (according to Pflaumann, 1975). $F_{1}$ represents Core 12309-2 (Thiede data); $F_{2}$ represents Core 12309-3; crosses in the lower part are calculated from data of Thiede (1977). The index stresses drastic changes of the faunal composition. Note the parallelism of the curves near 200 and $280 \mathrm{~cm}$, indicating the systematic difference, due to the different taxonomic concepts. (G) Estimated winter temperatures of the surface water (calculated by Thiede, 1977) with the CLIMAPprogram. No determinations were made for sediments above $260 \mathrm{~cm}$, Core 12309-3. (H) Dissolution-independent paleotemperature index, the ratio Globorotalia inflata/(Globorotalia inflata + Globigerina pachyderma). Crosses represent data recalculated from Thiede, 1977. Note the good correlation in Core 12309-3. Differences are due to different taxonomic and different samples. This index is sensitive to faunal changes in the cool temperate climate belt. 
of Globorotalia truncatulinoides was counted separately in Core 12309-3. Globigerina pachyderma (left and right-coiling forms) was used in a more restricted sense by Pflaumann. Data concerning Core 12309-2 were extracted from Thiede (Appendix, 1977).

Globorotalia cultrata occurs in the uppermost samples of Core 12309-2 down to $27.5 \mathrm{~cm}$ core depth and indicates an age of the Z-zone as described by Ericson and Wollin (1956). The stratigraphic presence or absence of only one tropical species group (Schott, 1935; Ericson and Wollin, 1956) cannot be used as a worldwide time-correct scale (see Pflaumann, 1975; Thiede, 1977). In low latitudes, such a "presence" zone is thicker than in higher latitudes, due to ecologic limits. The oxygen-isotope record, which is independent of such barriers, enables the establishment of latitudecompensated ratios. The definition of the $\mathrm{Y} / \mathrm{Z}$ boundary as the time of the strongest faunal changes at the base of the Holocene (Pflaumann, 1975), coincides with the oxygen-isotope Stage 1/2 boundary, although there were similar strong changes after the Alleröd.

The $\mathrm{X} / \mathrm{Y}$-zone boundary may be equivalent to the base of Stage 4, and warm X-zone correlates with Stage 5. Globorotalia menardii complex is not recorded in the $\mathrm{X}$-zone due to the high latitude. However, the extinction of Globorotaloides hexagonus, which is not as sensitive to cooler temperatures as the missing Globorotalia menardii complex, was observed by the end of the X-zone (sensu Pflaumann, 1975). Consequently, the presence of this species between 566 and $720 \mathrm{~cm}$ indicates an age of at least X-zone. This supports the identification of oxygen-isotope Stage 5. Changes in coiling ratios of Globorotalia truncatulinoides have been used for stratigraphic correlations at other sites in the Atlantic Ocean. A distinct change from predominantly rightto left-coiling was observed in Core 12309-3 at 12 to 10 $\mathrm{cm}$, owing to the observed discontinuity previously mentioned. Another section of predominant left-coiling occurs between 466 and $546 \mathrm{~cm}$, corresponding to the oxygen-isotope Stage 4 . The change in coiling sense between 546 and $566 \mathrm{~cm}$ supports the definition of the $\mathrm{X} / \mathrm{Y}$-zone boundary and is identical with the end of oxygen-isotope Stage 5.

Results of the planktonic foraminiferal counts were evaluated in various ways to maximize the paleoclimatic information. The planktonic foraminifers were divided into five ecological groups (Figure 3C, D; compare Pflaumann, 1975). Polar and sub-polar groups were dominant in most samples, while tropical and subtropical species increased in the uppermost $40 \mathrm{~cm}$ of Stage 1.

Paleotemperature Index 2 (Figure 3F) as defined by Pflaumann (1975) may be considered as a first approximation of the former surface-water temperature. Index 2 is defined as $[2 \times(e-a)+d-b] /(100-c)$, where $a, b$, $\mathrm{c}, \mathrm{d}$, and e are means proportions of polar, sub-polar, intermediate, sub-tropical, and tropical species (respectively) in percentages of planktonic foraminifers.

Estimated winter temperatures (Figure 3G) were based on $Q$-mode factor analyses of surface samples near the eastern North Atlantic margin and multivariate regression equations which quantified the relationships between hydrographic and biogenic deep-sea components (Thiede, 1977). The record of winter temperatures was selected, because it was the most significant of all the estimates tried. Application of the record assumes that dissolution and other secondary alterations did not affect the sediment and that relationships between hydrographic and biogenic variables have remained constant. The drastic climatic fluctuations of the late Pleistocene certainly must have had an influence on the deep-sea circulation patterns, and must be reflected in the CCD fluctuations.

A dissolution-independent temperature index was plotted (Figure $3 \mathrm{H}$ ) as a third condensation of the planktonic foraminiferal record. It is a simple ratio of resistant species dominant in the polar/sub-polar and the transitional associations.

Similar trends indicate that the results of the faunal distribution and paleotemperatures are independent of the applied methods. During Stage 1, two prominent warm culminations are visible in Core 12309-2 at 17.5 ("Atlanticum") and at 102 to $112 \mathrm{~cm}$ ("Alleröd/Bölling"'). Between these warm periods, minimum temperatures varied at sediment depths of 62 to $82 \mathrm{~cm}$.

At approximately 11,000 yr.B.P., the polar assemblage increased abruptly between 102 and $92 \mathrm{~cm}$. The correlation with the oxygen-isotope curve is excellent, however, the temperature indication of planktonic foraminifers is distinctly retarded during the warming phase from 70 to $30 \mathrm{~cm}$ (Core 12309-2). The dissolutionindependent temperature index signals an additional short-lasting minimum at $58 \mathrm{~cm}$. The anomalously high influence of the Alleröd/Bölling phase on the planktonic foraminiferal record is notable and has to be considered when determining the previous stratigraphic interpretations in this region.

The Y-zone contains three oxygen-isotopic stages: the cold Stages 2 and 4, and the relatively warm Stage 3 . Only slight variations in foraminiferal values were seen in Stage 2. There seems to be a trend of general cooling (see Figure $3 \mathrm{H}$ ); the extreme oscillations of the oxygenisotope curve were not strongly reflected. The tempperature minimum was determined at $150 \mathrm{~cm}$ (Core $12309-2$ ) with a $9.5^{\circ} \mathrm{C}$ winter temperature, compared to $15.5^{\circ} \mathrm{C}$ at present. Another temperature minimum was recorded at about $240 \mathrm{~cm}$ (in Core 12309-2, i.e., about $50 \mathrm{~cm}$ in Core 12309-3). Raised percentages of the polar assemblage (Figure 3C) in Core 12309-2, weakly indicated a first cool phase near the base of Stage 2 .

Stage 3 may be characterized by minor fluctuations of the extreme groups (Figure 3F) and shows a gradual tendency towards cooling. There are strong variations in the dissolution-independent temperature index (Figure $3 \mathrm{H})$ and a good correlation with the oxygen-isotopic curve in the lower part of Stage 3, but not in the upper part above $190 \mathrm{~cm}$ (Core 12309-3). Within Stage 3, the paleoclimatic fluctuations show good correspondence to the North American glacial cycles between the Port Talbot and Plum Point interstades (Bé et al., 1976). 
The planktonic foraminiferal assemblages of Stage 4 are divisible into two cold phases, separated by a warmer one near $500 \mathrm{~cm}$ core depth. The minimum temperatures occur near the end of Stage 4 at $470 \mathrm{~cm}$ in Core 12309-3 (Figure 3D, H).

The warm Stage 5 yields increased numbers of tropical and subtropical components at $566 \mathrm{~cm}$. Below this depth, a decrease in temperatures was indicated by both the planktonic and the benthic foraminiferal ratio, in contrast to the oxygen-isotope ratios. A temperature maximum occurs at $640 \mathrm{~cm}$, below the discontinuity at $613 \mathrm{~cm}$, but the foraminiferal curves do not parallel the extremely high amplitudes of the oxygen isotopes. The planktonic foraminifers gave no indication of the exact stratigraphic position of this core section (Sub-stage 5 c or e).

Some indexes and ratios were checked (fragmentation, dissolution indexes of Berger, 1973), in order to test the intensity of dissolution. However, the resulting curves did not reasonably correlate with any stratigraphic or environmental features.

\section{Sedimentary Record}

Cores 12309-2 and 12309-3 were analyzed for grain size, smear-slide, and coarse-fraction composition and carbonate content. (Most data were recalculated from Thiede, 1977; Chamley et al., 1977; and supplemented by our own data. Coarse fraction analysis was according to Sarnthein, 1971.)

Generally, the variations of simple sediment parameters reflect the single climatic peaks and stages only to a limited extent. This is unlikely to be the result of sample intervals which are too large or of silt samplings (e.g., 10-cm sections in Chamley et al., 1977), because sedimentation rates are high: 7 to $9 \mathrm{~cm} / 1000 \mathrm{yr}$ during the warm Stages 1 (Holocene) and 3, and 15 to 20 $\mathrm{cm} / 1000 \mathrm{yr}$ during the cold Stages 2 and 4 .

In both cores, cold Stages 2, 4, and ?6 are apparently paralleled by a slight relative increase of the fine fraction per total sample, but by an increase of the coarse fraction in the non-carbonate sediment fraction (Figure 1G, H).

High and low carbonate contents are noted from both cold and warm stages or substages and do not show any conclusive correlation. For example, a strong decrease of carbonate during the cold Stage 4 is opposed by relatively abundant carbonate during the other cold Stages 2 and 6 and by low carbonate at the (late) warm Stage 1, early Stage 3, and Sub-stage 5a. This irregular relationship is due to a rather complicated interaction of factors on the upper continental rise of western Africa. Cold stages can be characterized by (1) high terrigenous sediment input diluting the carbonates (Figure 1I, J), e.g., by an increased wind-dust discharge; (2) a possible increase of the shallow-water carbonate supply in case of low sea level and temporary dry shelves; (3) an upwelling-induced intensified planktonic shell production (Diester-Haass, 1977); (4) a generally lowered calcite compensation depth (Berger, in press) and reduced carbonate dissolution; and (5) a locally intensified dissolution, as a result of an upwelling-induced in- crease of deposition of organic matter. Accordingly, the carbonate content cannot be used as a straightforward stratigraphic tool to trace climatic stages at this continental-margin site position.

However, rather detailed peak-to-peak correlations occur between the oxygen-isotope stratigraphy and the coarse-fraction composition, e.g., the coarse-grained carbonate content (Figure 1I). Only a few low-carbonate/high-terrigenous maxima appear slightly delayed or are continuously increasing with ongoing cold stages. The trend of the terrigenous proportion is markedly exaggerated by the varying abundance of quartz, mica, and plant remains in the $>149 \mu \mathrm{m}$ fraction. Quartz maxima (never exceeding 0.2 to $0.4 \%$ ) mark the cold peaks and alternate with plant debris and abundant mica (Figure 1J). On the contrary, the stained-quartz fraction $>63 \mu \mathrm{m}$ (Figure $1 \mathrm{~K}$ ) culminates at the warm Stage 1, early Stage 3, and Sub-stage 5a, but is also still abundant in the lower Stage 4 .

Biogenic opal $>63 \mu \mathrm{m}$ (radiolarians; Diester-Haass, 1977) only correlates to the climatic phases in a broader sense because it is found to be abundant in major parts of the (early) cold stages, and also during most of warmer Stage 3 (Figure 1I). Volcanic glass (pumice) grains are confined to the disturbed lower parts of Core 12309-3 (Figure 1I).

The smear-slide estimates (Figure 1) revealed the order of magnitude of grain sizes and sediment composition, but generally gave no reliable information on the narrow-spaced sediment variations parallel to the climatic stages. Particular bias was found with the estimates of clay minerals. The carbonate fraction was judged too high ( 60 to $80 \%$ instead of 40 to $65 \%$ ). It is interesting to note that glauconite grains are concentrated to the Stage $2 / 3$ boundary and in lower Stage 3. A weak correlation is indicated between the late cold stages (2, 4, and ?5d) and increased abundance of pyrite.

\section{IMPLICATIONS FOR LATE PLEISTOCENE OCEANOGRAPHY AND CLIMATE AT THE NORTHWEST AFRICAN CONTINENTAL MARGIN}

\section{Rapid Variations of Surface Water Hydrography and Climate}

Extremely short-termed oscillations of surface-water temperature and salinity, and of climate are indicated by the oxygen-isotope curve (Figure 1C), and secondarily by the distribution of benthic and planktonic foraminifers (Figure 3). Because of the high local sediment accumulation rates at the northwestern African continental rise, most of the single $\delta^{18} \mathrm{O}$ stage can be further resolved into various shorter oscillations, each in the range of 1 per mil $\delta^{18} \mathrm{O}$ and lasting 2000 to 4500 years (i.e., 25 to $60 \mathrm{~cm}$ sediment thickness). Most oscillations match the isotopic curves from other parts of the ocean. For example, a well-separated "Alleröd" peak marks early Stage 1 and cool phases in Stage 3 follow warmer ones at the onset. The three cold peaks of Stage 2 and the preceding one at the end of Stage 3, the duration of which is already close to the mixing time of the oceans 
(Shackleton and Opdyke, 1976), bear close resemblance with regard to their amplitude, succession, and duration to Meteor Core 12392-1, $250 \mathrm{~km}$ farther south (Thiede, 1977). A close relationship is also seen with the cores from the Niger Delta (Pastouret et al., 1978), the Gulf of Mexico (Emiliani et al., 1975), the Panama Basin (Ninkovich and Shackleton, 1975) and the southern Atlantic (Hays et al., 1976).

Accordingly, long-term generalizations over more than one stage appear misleading. For example, it is impossible to apply a single climatic regime or oceanographic pattern to an extended period such as the Y-zone, i.e., the former Würm (see Diester-Haass, 1976; Chamley et al., 1977).

Several isotopic stage or phase boundaries are marked by steep isotopic gradients despite a smoothing effect of widely observed sediment bioturbation (cf. Stage $1 / 2$ and $2 / 3$ boundaries and several inner-stage fluctuations). As a consequence, many transitions between different hydrographic-climatic regimes are identified as rapid episodes which might have occurred within a few hundred years of the depositional record.

In general, the various paleotemperature curves based on planktonic foraminifera (Figure 3) closely resemble the zig-zags of the surface-water oxygenisotopic curve. It appears that during cold stages, the foraminiferal peaks precede them by some 10 to $20 \mathrm{~cm}$; however, further investigations are required. The amplitude of the pulses of the isotopic and the foraminiferal curves differs significantly and, notably, in a systematic way. During the warm isotopic stages and phases, the temperature indication by the planktonic foraminifers varies to a greater extent than during the cold stages, for example, the 18,000-year level is only weakly recorded. The species group which is more resistant to dissolution forms exceptions to this rule (Figure 3 ). Therefore, a reliable identification of the isotopic stages by the assemblages of only planktonic foraminifers is either difficult or impossible.

Nevertheless, the varying extent of the temperaturepeak oscillations of foraminifers can be tentatively used to decipher some of the ambiguous meaning of the isotopic record: its change between the last glacial and the present interglacial amounts to about 2.5 per mil. About 1.5 per mil of this amplitude may be attributed to the waxing and waning of the ice caps and their effects on the global isotopic composition of ocean water (Duplessy, 1978; Shackleton, 1977a). The remaining 1 per mil could well reflect differences of local surface-water temperatures in the upwelling region off western Africa (Thiede, 1977; McIntyre et al., 1976). This interpretation now appears well confirmed by the clearly reduced response of the foraminiferal curve to climatic oscillations during cold stages. Under these conditions, temporally short and rapid variations of the ice-cap volumes are well-reflected in the isotopic record, only slightly in the planktonic temperature curve.

The complex influences of upwelling on temperature and salinity (Mittelstaedt, 1972) also affect the local oxygen-isotope record. In terms of isotopic composition, however, the effects of the present supply of cold upwelling waters to the sea surface will be roughly balanced by their lowered salinity. Accordingly, oxygen isotopes would not strongly reflect the intensity of upwelling.

A higher intensity of upwelling may be indicated by the dissolution-independent foraminiferal index (Figure $3 \mathrm{H}$; overemphasized temperature minima). It may also be indicated by extremely high abundances of both Globigerina bulloides and Globigerina pachyderma (Figure 3C, D), which do not agree with the isotope record; for example, at the end of Stage 3 (Core $12309-3,124 \mathrm{~cm}$ ) and in early Stage 1 (Core 12309-2, 62 $\mathrm{cm})$. This interpretation corresponds with the abundance of some benthic foraminifers, and of radiolarians and biogenic opal in general, which is believed to provide a reliable record of upwelling (Diester-Haass, 1977). On the whole, opal-indicated upwelling maxima parallel the cold oxygen-isotopic stages and phases (Figures 1 and 3). However, the correlation is irregular as shown during the temperate warm Stage 3 by opal maxima. The same applies to the planktonic foraminiferal record: the polar and subpolar faunal elements reduce the surface temperature estimates not only during generally cold phases, but also during warm pulses of the oxygen-isotope ratios.

The carbon-isotope record, especially the short-lasting maximum of $\delta^{13} \mathrm{C}$ in the foraminiferal carbonates of early Stage 1, could reflect a suite of different, environmental factors (sometimes operating sympathetically together); for example: (1) the enhanced concentration of light $\mathrm{CO}_{2}$ in the upwelling water ascending from the low-oxygen layer, and (2) increased fertility and/or a reduced $\mathrm{CO}_{2}$ content of the ocean removing the light carbon as nonoxidized organic matter from the surfacewater balance to the bottom sediment. The species $G$. bulloides itself could also effect a change of the carbonisotopic test composition owing to changes of metabolic activity of its symbionts.

\section{Deep-Water Record of Benthic Foraminifers}

The general correlation between the benthic fluctuation (WBF-curve) and shifts of the planktonic foraminiferal curves support the theory that climatically induced changes in the surface-water regime are associated with drastic changes in the Atlantic deep water circulation (Streeter, 1973; Schnitker, 1974). However, the reduced degree of correlation during Stage 3 may indicate that smaller changes in the surface waters are not always paralleled by equivalent shifts of the benthic foraminiferal population and the bottom-water conditions.

Streeter (1976; personal communication, 1977) suggests that the cessation of flow of oxygen-rich Atlantic deep water (presently derived from the Arctic region) is responsible for the drastic changes in the benthic community. Oxygen-poor waters originating from the south are believed to have replaced the North Atlantic deep water during cold periods. This caused increased proportions of Uvigerina, which may be particularly well adapted for such conditions. The present-day distribution of Uvigerina peregrina s.l. on the eastern North Atlantic slope and rise between England and western Afri- 
ca supports this explanation, with the distribution boundaries running vertically across the continental slope and the highest abundances being found in the south.

It is remarkable, that the extraordinary increase of Melonis zaandami (240 to $200 \mathrm{~cm}$ in Core 12309-3) corresponds to a similar increase of the planktonic form Globigerina bulloides, and additionally with a dramatic increase of the foraminiferal number. During this interval, the planktonic and the benthic curves appear somewhat too "cool" in comparison with the isotopic curve. Furthermore, biogenic opal also increases. Local upwelling and surface-water circulation changes not affecting the global oxygen-isotope balance are believed to be responsible for the Melonis-maximum. It may also reflect a real productivity maximum induced by increased supply of upwelling-produced detritus.

The changes between different benthic foraminiferal communities occur with a steep gradient similar to that of the oxygen-isotopes. The pattern of climatic cycles can not be fully resolved by less than five samples per 1.5 meters (i.e., one section in a DSDP core at Site 397).

\section{Sedimentary Record of Continental Aridity and Wetness}

In addition to the bedrock composition, the continental climate and the climatic changes of northwestern Africa can be regarded as the primary factors controlling the amount and composition of terrigenous input to the continental margin of the eastern North Atlantic. A detailed knowledge of the evolution of land climate during the last 25,000 years, the period for which sufficient ${ }^{14} \mathrm{C}$ evidence is available (Sarnthein, 1978, in press), provides a calibration tool to interpret the sedimentary record on the continental rise.

However, fundamental problems arise from the lack of reliable criteria (Sarnthein and Diester-Haass, 1977) to differentiate between dust-sized particles supplied to marine sediments by rivers (fluvio-marine) and by wind (eolo-marine). The significance of terrigenous, especially eolo-marine sediment is further confused by: (1) the general shortness of the late Pleistocene climatic phases, particularly the ones in North Africa at latitudes north of 22 to $24^{\circ} \mathrm{N}$ (Sarnthein, in press); (2) the possibility of non-uniformitarian high paleowind speeds causing coarse-grained dust loads which find no modern analogue (Parkin and Shackleton, 1973; Sarnthein and Diester-Haass, 1977; Jaenicke, 1977); (3) the unknown paleoposition of anticyclones and wind belts of the higher atmospheric levels, resulting in unknown dust trajectories which partially determine the grain size of the dust discharge over the sea (Jaenicke, 1977); and (4) the poorly understood climatic evidence of eolian dust, which might originate from both fully arid deserts and semi-arid Sahel zones.

To solve these complex questions, a simple straightforward use of (reddish) stained quartz grains as a tracer for wind dust and aridity (Diester-Haass, 1976; Chamley et al., 1977; Diester-Haass, this volume) is not adequate. For example, it would be inconsistent with the results of recent investigations of modern near-shore and on-shore sedimentary environments in northwestern Africa (Koopmann, 1975; Koopmann et al., in press; Kiper, 1977; Sarnthein, personal communication). These authors have shown that only 3.5 to 8.5 per cent (rarely up to $13 \%$ ) of the eolian quartz grains (63 to $125 \mu \mathrm{m}$ ) are stained in the sediments of the Baie du Levrier. This bay lies at $21^{\circ} \mathrm{N}$ latitude, directly off the center of aridity of the present Sahara desert and in the region with maximum dust-storm activity (Dubief, 1952; Mainguet and Canon, 1976). On the other hand, farther south at $16^{\circ} \mathrm{N}$ latitude, the wind dust of the semi-arid Senegal Delta contains up to 74 per cent stained quartz (63 to $125 \mu \mathrm{m}$ ) as compared to the load of the river Senegal itself with 35 to 55 per cent stained quartz. The main sources of reddish quartz in the Senegal Delta are (1) a widespread Neogene paleosoil crust ("cuirasse ferrugineuse") rich in quartz; (2) reddish "Ogolien" dunes of Stages 2 and 4 containing reworked lateritic material originating from various previous warm-humid Pleistocene phases (Michel, 1973); and (3) probably middle Holocene lateritic crusts (Petit-Maire et al., 1977).

In summarizing, it turns out that the quartz color as well as the whole composition of wind dust will mainly integrate the kind of material which is characteristic of the eroding hinterland. In this sense, stained quartz dust originates from warm-humid regions, or those having had this type of climate (Folk, 1976). However, there is no specific evidence that stained quartz is significant for desert environments; accordingly, the term "desert quartz" (Radczewski, 1937) should be abandoned. According to Folk (1976), arid environments only contribute additional $\mathrm{SiO}_{2}$ skinlets at the quartz surfaces. The $\mathrm{SiO}_{2}$ will further fix already existing lateritic-hematitic clay spots and delay the destruction of the stain during wind transport.

With regard to the climatic fluctuations on land, a recent compilation of the ${ }^{14} \mathrm{C}$ dated-record (Sarnthein, 1978 , in press) in the northwestern Sahara shows that the very major phase of active sand deserts occurred during cold Stage 2 (another one probably occurred in Stage 4). A phase of rather general wetness (rainfall + snowmelt - evaporation) precedes in late Stage 3 . The time slice of extreme aridity gradually thins out, from 21,000 to $12,000 \mathrm{yr}$ B.P. in lower latitudes $\left(10\right.$ to $\left.22^{\circ} \mathrm{N}\right)$ to approximately 20,000 to 17,800 yr B.P. at 24 to $36^{\circ} \mathrm{N}$. The reduced duration in the more northerly latitudes probably demonstrates a slight increase of wetness towards Mediterranean latitudes by decreasing temperatures and evaporation.

On the contrary, the hypsithermal phase of Stage 1 at 6,000 yr B.P. displays a generally increased precipitation, i.e., prairie-type savannahs and lakes as the dominating environments. Since 5500 and especially after $3000 \mathrm{yr}$ B.P., sand dunes and sebkhas have gradually returned as signs of aridity. Oscillatory phases of climate occur during the transition from Stage 2 to Stage 1 . They were characterized by (1) a slight gradual decrease of wetness from the northern Sahara to the south, until the massive overall onset of humidity at some $12,500 \mathrm{yr}$ B.P.; and (2) some short but widespread phases of sand-desert re- 
activation at around 9800 to 8600 and 7500 to $6900 \mathrm{yr}$ B.P. (possibly also around 14,000 yr B.P.). The outlined evolution of humidity and aridity during Stages 2 and 1 is also in general agreement with the climatic history of the northwestern Sahara coastal margin between the Atlas and Senegal (Beaudet et al., 1976; Delibrias et al., 1976a, b; Michel, 1973; Ortlieb, 1975; Petit-Maire et al., 1977).

The short-term alternating climates of the Sahara with maximal aridity during extreme cold, and an extreme of wetness during maximal warmth cannot confirm earlier interpretations of the marine sedimentary record in terms of a humid glacial and an arid interglacial north of $20^{\circ} \mathrm{N}$ latitude (Diester-Haass, 1976; Chamley et al., 1977). It seems necessary to re-interpret some of the main sedimentary features in close relation to the oscillations of the isotopic curve. For example, cold stages and phases are paralleled by peaks of both terrigenous sediment supply (Figure $1 \mathrm{G}, \mathrm{I}$ ) resulting in high sedimentation rates of up to $20 \mathrm{~cm} / 1000$ years, and terrigenous grain sizes. The latter are made most obvious by peaks of quartz (up to $0.4 \%$ ) and of mica in the $>150 \mu \mathrm{m}$ fraction (Figure 1J). Calibrated against the record of land climate, the terrigenous part of these sediment sections can now be interpreted as eolian dust, i.e., a marine loess equivalent.

At no stratigraphic level is conclusive evidence of fluvial input found in the cores. For example, a few plant fibers occur mainly at the Stage $2 / 3$ boundary and the "Allerod" phase, and could be wind-derived (as compared with up to $50 \%$ plant remains in the coarse fraction of sediments off the Senegal Delta; Kiper, 1977). The fine-sand sized quartz grains do not represent evidence neither contrary to wind transport, nor for river supply (cf. Chamley et al., 1977). In reality, the maxima of quartz $>150 \mu \mathrm{m}$ only amount to 0.02 per cent of the bulk non-carbonate fraction. This order of magnitude is easily explained as the "coarse tail" of an eolian dust load, providing the trajectory from the dust's source is short (Jaenicke, 1977; Junge, 1977; Schütz, 1977) and the vigor of the off-shore Trade Winds in the Wheel-Round Latitudes increased only slightly during glacial stages (Manabe and Hahn, in press; Parkin and Shackleton, 1973; Sarnthein and Diester-Haass, 1977). For example, during phases of low sea level the minimum trajectory to DSDP Site 397 was as short as 75 to $80 \mathrm{~km}$ off-shore. However, it is generally difficult to separate the role of increased paleowind strength from the influence of a reduced trajectory on the basis of dust-grain size only.

Warm oxygen-isotopic stages show reduced sedimentation rates and only minor fine-grained terrigenous sediment supply. A significant proportion of the fine quartz grains is stained reddish, especially from the late warm stages (e.g., late Stage 1 and Sub-stage 5a). This composition might reflect the beginning of erosion of red soils from the Sahel zone during the initial phases of Sahara aridification, which slightly preceded the general phases of climatic deterioration (Sarnthein, in press; Shackleton, 1977).
In Core 12309-3, clay minerals do not show a reliable trend which could be related to the land-climate history (Chamley et al., 1977). According to our state of knowledge, this is linked less to the position of the site in a transitional climate belt, but rather to the local vertical structure of current systems as recently pointed out in detail by McMaster et al. (1977) and McGrail (1977) and to the source-rock composition of dust.

\section{Downslope Sediment Displacement as Compared to Sea-Level Changes}

A downslope displacement of sediments is particularly well demonstrated by high proportions of displaced benthic shallow-water species, found in the smaller fractions: 15 to 25 per cent in the 63 to $125 \mu \mathrm{m}$ fraction and up to 3 per cent in the 125 to $250 \mu \mathrm{m}$ fraction (Table 2). The identification of these displaced foraminifers has been hampered by insufficient knowledge of Pleistocene shelf and upper slope associations. According to the present depth distribution, at least the following species can be considered as transported downslope from a shallow-water environment: Bolivina pseudoplicata, $\boldsymbol{B}$. difformis, B. variabilis, Eoeponidella pulchella s.1., and Nonionella cf. japonica (Lutze, in preparation). In contrast to a first-glance impression, significant percentage differences of allochthonous benthic components between the warm and cool stages have not been found.

The true proportion of allochthonous species should be even higher than presented in Table 2 . Thus, a significant part of the high accumulation rates at Site 397 probably originates through downslope transport. It may amount up to one-third of the deposited matter in the sand fraction. This is in good agreement with the occurrence of abundant shelf-derived glauconite particles in the sediments of Stages 2 and 3 (Figure 1M).

According to Bein and Fütterer (1977), the underlying transport mechanism is not interpreted as a direct grain flow, but rather by continuous particle-by-particle displacement. This mechanism also affects the terrigenous sediment fraction, a part of which will be derived from intermediate depositional environments at the upper continental slope.

Similar to the early Miocene section of DSDP Site 397 , distinct disconformities and slumping activities oc-

TABLE 2

Allochthonous Components of the Benthic Foraminiferal Fauna

\begin{tabular}{|c|c|c|c|c|c|c|}
\hline 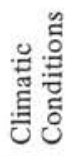 & $\begin{array}{c}\text { Meteor } \\
\text { Core }\end{array}$ & $\begin{array}{c}\text { Core } \\
\text { Depth } \\
(\mathrm{cm})\end{array}$ & $\begin{array}{c}\text { WBF } \\
(\%)\end{array}$ & $\begin{array}{c}>250 \mu \mathrm{m} \\
(\%)\end{array}$ & $\begin{array}{c}250 \\
\text { to } \\
125 \mu \mathrm{m} \\
(\%)\end{array}$ & $\begin{array}{c}125 \\
\text { to } \\
63 \mu \mathrm{m} \\
(\%)\end{array}$ \\
\hline$\sum_{\frac{\Sigma}{k}}$ & $\begin{array}{l}12309-3 \\
12309-3 \\
12309-2 \\
12309-3\end{array}$ & $\begin{array}{c}626 \\
566 \\
20 \\
\text { surface }\end{array}$ & $\begin{array}{l}59 \\
57 \\
44 \\
42\end{array}$ & $\begin{array}{l}0 \\
0 \\
0 \\
3\end{array}$ & $\begin{array}{l}1 \\
3 \\
2 \\
1\end{array}$ & $\begin{array}{l}15 \\
21 \\
21 \\
18\end{array}$ \\
\hline 8 & $\begin{array}{l}12309-3 \\
12309-3 \\
12309-3 \\
12309-3\end{array}$ & $\begin{array}{r}688 \\
104 \\
466 \\
34\end{array}$ & $\begin{array}{r}17 \\
12 \\
11 \\
5\end{array}$ & $\begin{array}{l}0 \\
0 \\
0 \\
0\end{array}$ & $\begin{array}{l}1 \\
1 \\
3 \\
0\end{array}$ & $\begin{array}{l}27 \\
25 \\
25 \\
24\end{array}$ \\
\hline
\end{tabular}


cur in combination with the only occurrences of pumice in Core 12309-3 (late Stage ?6, Substage ?5c).

\section{ACKNOWLEDGMENTS}

We would like to thank the shipboard party of Meteor Leg 25 for retrieving the cores; A. Wetzel, Kiel, for his comments on sediment structures; Dr. W. H. Berger, SIO, and Dr. St. Streeter, LDGO, for helpful discussions and suggestions; H. Cordt for careful measurement of the stable isotopes; and M. Whiticar for editing the English of this paper. Financial support from the Deutsche Forschungsgemeinschaft, Bonn, is appreciated.

\section{REFERENCES}

Bé, A.W.H., Damuth, J.E., Lott, L., and Free, R., 1976. Late Quaternary climatic record in western Equatorial Atlantic sediment, Geol. Soc., Mem. 145, p. 165-200.

Bé, A.W.H. and Hamlin, W.H., 1967. Ecology of Recent planktonic foraminifera: Part 3. -Distribution in the North Atlantic during the summer of 1962, Micropaleuntology, v. 13, p. 87-106.

Bé, A.W.H., Hembleben, C., Anderson, O.R., Spindler, M., Hacunda, J., and Tuntivate-Choy, S., 1977. Laboratory and field observations of living planktonic foraminifera, Micropaleontology., v. 23, p. 155-179.

Beaudet, G., Michel, P., Nahon, D., Oliva, P., Riser, J., and Ruellan, A., 1976. Formes, formations superficielles et variations climatiques récentes du Sahara occidental, Rev. Géor. phys. Geol. dyn., v. 18, p. 157-173.

Bein, A. and Fütterer, D., 1977. Texture and composition of continental shelf to rise sediments off the northwestern coast of Africa: An indication for downslope transportation, "Meteor"' Forsch.-Ergebn., v. C27, p. 46-74.

Berger, W.H., 1973. Deep-sea carbonates: Pleistocene dissolution cycles, J. Foram. Res., v. 3, p. 187-195.

1978. Deep-sea carbonate: the deglaciation preservation spike in pteropods and foraminifera, Nature, v. 269, p. 301-304.

Chamley, H., Diester-Haass, L., and Lange, H., 1977. Terrigenous material in East Atlantic sediment cores as an indicator of NW African climates, "Meteor" Forsch.-Ergebn., v. C26, p. 44-59.

Delibrias, G., Ortlieb, L., and Petit-Maire, N., 1976. New ${ }^{14} \mathrm{C}$ data for the Atlantic Sahara (Holocene): Tentative interpretation, J. Human Geol., v. 5, p. 535-546.

Delibrias, G., Rognon, P., and Weisrock, A., 1976. Datation de plusiers épisodes à "limons roses" dans le Quaternaire récent de l'Atlas Atlantique marocain, C.R. Acad. Sci., Paris, v. D282, p. 593-596.

Diester-Haass, L., 1976. Late Quaternary climatic variations in northwest Africa deduced from East Atlantic sediment cores, Quat. Res., v. 6, p. 299-314.

1977. Radiolarian/planktonic foraminiferal ratios in a coastal upwelling region, J. Foram. Res., v. 7, p. 26-33.

Diester-Haass, L., Schrader, H.J., and Thiede, J., 1973. Sedimentological and paleoclimatological investigations of two pelagic ooze cores off Cape Barbas, North-West Africa, "Meteor" Forsch.-Ergebn., v. C16, p. 19-66

Dreimanis, A. and Goldthwait, R.P., 1973. Wisconsin glaciation in the Huron, Erie and Ontario lakes, G.S.A. Mem. 136, p. 71-106.

Dubief, J., 1952. Le vent et le déplacement du sable au Sahara, Travaux Inst. Rech. Sahariennes, v. 8, p. 123-162.
Duphorn, K., 1976. Kommt eine neue Eiszeit?, Geol. Rdsch, v. 65 , p. $845-864$.

Duplessy, J.C., 1978. Isotope studies. In Gribbin, J. (Ed.), Climatic change: Cambridge (Cambridge University Press), p. 46-67.

Emiliani, C., Gartner, S., Lidz, B., Eldridge, K., Elvey, D.K., Huang, T.Ch., Stipp, J. J., and Swanson, M. F., 1975. Paleoclimatological analysis of late Quaternary cores from the Northeastern Gulf of Mexico, Science, v. 189, p. 10831088.

Ericson, D.B. and Wollin, G., 1956. Correlation of six cores from the equatorial Atlantic and the Caribbean, Deep-Sea Res., v. 3, p. $104-125$.

Folk, R.L., 1976. Reddening of desert sands Simpson Desert, N.T. Australia, J. Sed. Petrol., v. 46, p. 604-615.

Geyh, M.A., 1976. ${ }^{14} \mathrm{C}$ routine dating of marine sediments, Ninth Radiocarbon Conf., Proc., Los Angeles; San Diego.

Hays, J.D., Imbrie, J., and Shackleton, N.H., 1976. Variations in the Earth's Orbit: Pacemaker of the Ice Age, Science, v. 194, p. 1121-1132.

Jaenicke, R., 1977. Monitoring and critical review of the estimated source strength of mineral dust from the Sahara. Workshop on Sahara dust transport at Gothenburg/Sweden from 25th to 27th April 1977.

Junge, C., 1977. The importance of mineral dust as an atmospheric constituent, Unpublished ms., SDT-Workshop Gothenburg.

Kiper, M., 1977. Sedimente und ihre Umwelt im Senegaldelta, Unpublished Master Thesis, Geol. Inst. Kiel University p. 1-61.

Koopmann, B., 1975. Siltmergel and Schillsande in der nordlichen Baie du Levrier, Unpublished Master Thesis, Geol. Inst. Kiel University, p. 1-51.

Koopmann, B., Lees, A., Piessens, P., and Sarnthein, M., in press. Skeletal carbonate sands and wind-derived silty marls off the Saharan coast: Baie du Levier, Arguin Platform, Mauritania, "Meteor"' Forsch.-Ergebn., v. C30.

Lutze, G.F., 1978. Neogene benthonic foraminifera from Site 369, Leg 41. In Lancelot, Y., Seibold, E., et al., Initial Reports of the Deep Sea Drilling Project, v. 41: Washington (U.S. Government Printing Office), p. 659-666.

Mainguet, M. and Canon, L., 1976. Vents et paléovents du Sahara. Tentative d'approche paléoclimatique, Rev. Géogr. Phys. Geol. Syn., v. 18, p. 241-250.

Malmgren, B.A. and Kennett, J.P., 1977. Biometric differentiation between Recent Globigerina bulloides and Globigerina falconensis in the Southern Indian Ocean, J. Foram. Res., v. 7, p. 130-148.

Manabe, S. and Hahn, D.G., 1977. Simulation of the tropical climate of an ice-age, J. Geophys. Res., v. 27, p. 3889-3909.

McGrail, D.W., 1977. Sedimentological and physical oceanographic evidence of a shelf edge counter-current off Guinea, Guinea and Sierra Leone, J. Sediment. Petrol., v. 47, p. 915925.

McIntyre, A., Kipp, N.G., Bé, A.W.H., Crowley, Th., Kellog, Th., Gardner, J.V., Press, W., and Ruddiman, W.F., 1976. Glacial North Atlantic 18,000 Years Ago: A CLIMAP Reconstruction, Geol. Soc. Am., Mem. 145, p. 4376.

McMaster, R.L., Betzer, P.R., Carder, K.L., Miller, L., and Eggimann, D.W., 1977. Suspended particle mineralogy and transport in water masses of the West African Shelf adjacent to Sierra Leone and Liberia, Deep-Sea Res., v. 24, p. 651-665.

Michel, P., 1973. Les bassins des fleuves Sénégal et Gambie, étude géomorphologique, Mém. ORSTOM, 3 tomes, p. 1-752. 
Mittelstaedt, E., 1972. Der hydrographische Aufbau und die zeitliche Variabilität der Schichtung und Strömung im nordwest-afrikanischen Auftriebsgebiet im Frühjahr 1968, "Meteor"' Forsch.-Ergebn, v. 11, p. 1-57.

Ninkovich, D. and Shackleton, N.J., 1975. Distribution, stratigraphic position and age of ash layer "L" in the Panama Basin region, Earth Planet. Sci. Lett., v. 27, p. 1-20.

Ortlieb, L., 1975. Recherches sur les formations plioquaternaires du littoral Ouest-Saharien, These third cycle, Univ. P. \& M., Curie.

Parkin, D. W. and Shackleton, N. J., 1973. Trade wind and temperature correlations down a deep-sea core off the Sahara Coast, Nature, v. 245, p. 455-457.

Pastouret, L., Chamley, H., Delibrias, G., Duplessy, J.C., and Thiede, J., 1978. Late Quaternary climatic changes in Western Tropical Africa deduced from deep-sea sedimentation off the Niger delta, Ocean. Acta., v. 1, p. 217-232.

Petit-Maire, N., Delibrias, G., and Ortlieb, L., 1977. New radiometric data for the Atlantic Sahara (Holocene, $19^{\circ}$ to $\left.28^{\circ} \mathrm{N}\right)$. Tentative interpretations, 10th INQUA Congr. Birmingham, Abstract.

Pflaumann, U., 1975. Late quaternary stratigraphy based on planktonic foraminifera off Senegal, "Meteor" Forsch.Ergebn. v. C23, p. 1-46.

Radczewski, O.E., 1937. Die Mineralfazies der Sedimente des Kapverden-Beckens. In C.W. Correns: Die Sedimente des äquatorialen atlantischen Ozeans, Wiss. Ergebn. Deut. Atlant. Exped. "Meteor", p. 262-277.

Sarnthein, M., 1971. Oberflächensedimente im Persischen Golf und Golf von Oman. II. Quantitative Komponentenanalyse der Grobfraktion, "Meteor"' Forsch.-Ergebn., v. C5, p. 1-113.

1978. Sand deserts during glacial maximum $(18,000$

yr.B.P.) and climatic optimum (6000 yr.B.P.), Nature, v. 271 , p. 43-46.

in press. Die Sandwüsten der Erde: Heute, im Hochglazial (18,000 J.v.h.) und im Klimaoptimum (6000 J.v.h.), Geol. un Rdsch.

Sarnthein, M. and Diester-Haass, L., 1977. Eolian-sand turbudites, J. Sediment. Petrol., v. 47, p. 868-890.

Schnitker, D., 1974. West Atlantic abyssal circulation during the past 120,000 years, Nature, v. 248 , p. $385-387$.

Schott, W., 1935. Die foraminiferen in dem äquatorialen Tiel des Atlantischen Ozeans, Wiss. Ergebn. Deut. Atlant. Exped. Forsch.-Vermessungsschiff, "Meteor", v. 3, p. $43-134$.
Schutz, L., 1977. Sahara dust transport over the North Atlantic ocean - Model calculations and measurements, unpublished manuscript, SDT-Workshop Gothenburg.

Seibold, E., 1972. Cruise 25/1971 of R. V. "Meteor': Continental margin of West Africa general report and preliminary results, "Meteor"'Forsch.-Ergebn., v. C10, p. 17-38.

Shackleton, N.J., 1977a. The ocean oxygen-isotope record: stratigraphic tool and paleoglacial record. X. INQUA Congr., Birmingham.

, 1977b. The oxygen-isotope stratigraphic record of the late Pleistocene, Phil. Trans. Roy. Soc. London, ser. B, v. 280 , p. $169-182$.

Shackleton, N.J. and Kennett, J.P., 1975. Paleotemperature history of the Cenozoic and the initiation of Antarctic glaciation: Oxygen and carbon isotope analyses in DSDP Sites 277, 279, and 281. In Kennett, J.P., Houtz, R. et al., Initial Reports of the Deep Sea Drilling Project, v. 29: Washington (U. S. Government Printing Office), p. 743-955.

Shackleton, N.J. and Opdyke, N.D., 1973. Oxygen isotope and paleomagnetic stratigraphy of equatorial Pacific core V 28-238: Oxygen isotope temperatures and ice volumes on a $10^{5}$ year scale, Quat. Res., v. 3, p. 39-55.

1976. Oxygen isotope and paleomagnetic stratigraphy of Pacific core V 18-239: Late Pliocene to latest Pleistocene, G.S.A. Memoir 145, p. 449-464.

Streeter, S.S., 1973. Bottom water and benthonic foraminifera in the North Atlantic glacial-interglacial contrasts, Quat. Res., v. 3, p. 131-141.

1976. Deep-water benthic foraminiferal faunas in the Atlantic during the late Pleistocene - the significance of Uvigerinid peaks, Am. Geophys. Union Trans., v. 57, p. 258.

Stuiver, M. and Yang, I.C., 1977. Early and Mid-Wisconsin Chronology $(40,000$ to 75,000 years B.P.), X. INQUA Congr., p. 443, Abstract.

Thiede, J., 1975. Shell- and skeleton-producing plankton and nekton in the eastern North Atlantic Ocean, "Meteor" Forsch.-Ergebn., v. C20, p. 33-79.

1977. Aspects of the variability of the Glacial and Interglacial North Atlantic eastern boundary current (last 150,000 years), “Meteor"' Forsch.-Ergebn., v. C28, p. 1-36.

Vergnaud-Grazzini, C., 1975. ${ }^{18} \mathrm{O}$ changes in foraminifera carbonates during the last $10^{5}$ years in the Mediterranean Sea, Science, v. 190, p. 272-274. 